\title{
EVALUATION OF INTRA-ARTICULAR COLLOIDAL GOLD AU 198 IN THE TREATMENT OF PERSISTENT KNEE EFFUSIONS*
}

\author{
BY \\ BARBARA M. ANSELL, ANNE CROOK, J. R. MALLARD, \\ AND E. G. L. BYWATERS \\ From the Departments of Medicine and Physics, Hammersmith Hospital, London
}

In the management of persistent knee effusions, synovectomy may be useful but surgical removal is often far from complete and recurrences are common. The present study reports an attempt to produce a radiation synovectomy, using the principle

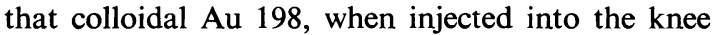
joint, would behave like other particles and localize on the synovial membrane. Au 198 has a half life of 2.7 days and emits both beta and gamma rays; since the average range of the beta rays in tissue is approximately $1 \mathrm{~mm}$., it was thought feasible that destruction of the superficial layers of the synovial membrane should occur if a sufficiently large radiation dose could be delivered.

\section{Pilot Study}

A pilot study was undertaken to see if satisfactory diffusion throughout the knee joint and localization on the synovial membrane occurred. In four patients suffering from rheumatoid arthritis with persistent knee effusions, an aspirating needle was placed in the knee joint and $10 \mathrm{ml}$. synovial fluid was removed for estimation of viscosity, protein, cell content, and culture. A tracer dose of $50 \mu \mathrm{c}$. $198 \mathrm{Au}$, previously prepared in $10 \mathrm{ml}$. saline and sterilized by autoclaving, was injected through the same needle, which was then removed. The site of puncture of the needle was marked and the depth that it penetrated into the knee was noted. The puncture wound was sealed with collodion and the patient was asked to walk about. At 1, 6, and 24 hours a scan of the knee was made, initially using a well-collimated scintillation counter with a $\frac{1}{2}$ in. diameter sodium iodide crystal and later an automatic scanner. At 6 and 24 hours the regional lymph glands were also checked, and at 24 hours

* Given at the Heberden Society on February 16, 1962. Discussion published with report of meeting, Annals (1962), 21, 219.
$10 \mathrm{ml}$. heparinized blood was examined for the presence of radioactivity. At 1 hour, the scan of the knee showed the gold to have diffused throughout the synovial cavity (Fig. 1), and there was little change in the ensuing scans at 6 and 24 hours. As well as outlining the cavity of the knee, outpouchings of the synovial membrane which were in free communication could be demonstrated.

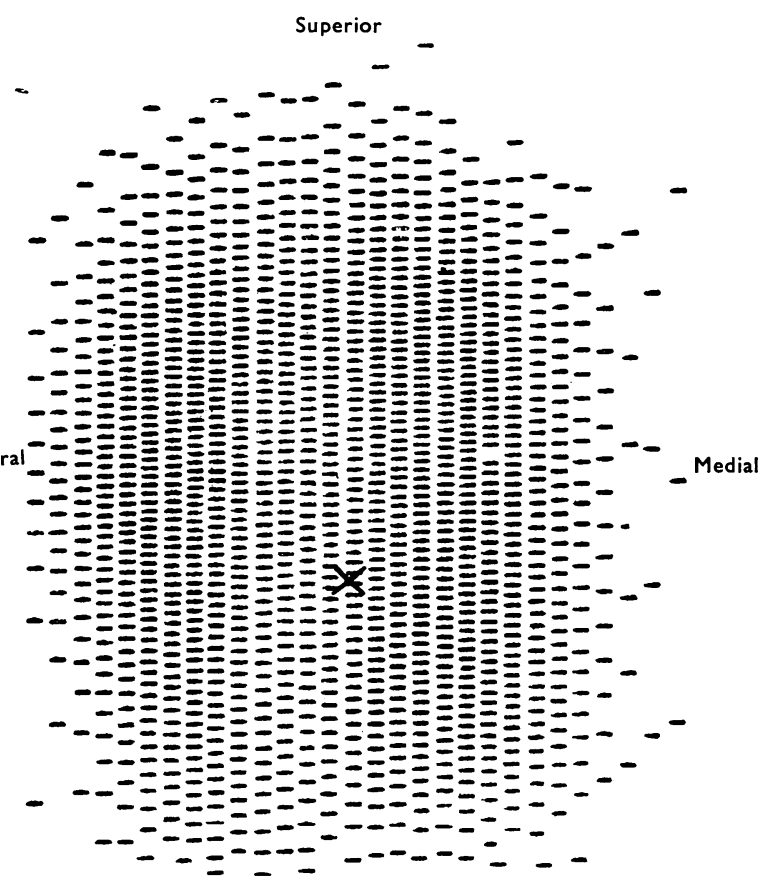

Fig. 1.-Scan of knee $2 \mathrm{hrs}$ after injection of $198 \mathrm{Au}$.

After the 24-hour scan, the knee was aspirated to dryness, the volume of fluid obtained varying from 25 to $50 \mathrm{ml}$. in these four patients. $10 \mathrm{ml}$. synovial 
fluid was checked for radioactivity and the remainder examined as previously described. There was less than 1 per cent. of the injected radioactivity in the synovial fluid and none could be detected in the lymph glands or in the blood. A further patient about to undergo surgery on the knee was investigated in this way and the biopsy specimen of synovial membrane had a high degree of radioactivity. However, in one patient with degenerative joint disease and only a very small effusion in the knee, the synovial cavity was not completely outlined even at 48 hours, although little radioactivity could be detected in the $7 \mathrm{ml}$. fluid then aspirated.

From this work, it was concluded that, provided there was an effusion of moderate size, the introduction of colloidal Au 198 into the knee joint was followed by its rapid diffusion throughout that cavity followed by localization on the synovial membrane. It was therefore decided to study the effect of therapeutic doses of $\mathrm{Au} 198$ in patients in whom unilateral or bilateral knee effusions were the major or only disability. All had received one or more intra-articular injections of corticosteroid with only very transient benefit.

\section{MaIn Study}

Thirty injections have been given in 24 patients and all have been followed for a minimum of one year. Initial assessment as an out-patient consisted of measuring the circumference of the knee at different distances from the superior border of the patella and then aspirating to dryness, recording the volume obtained, remeasuring the circumference of the knee, and noting the severity of the soft tissue swelling. When the knee effusion recurred, the patient was admitted to hospital and, in addition to the routine clinical examination, the circumference, range of movement, presence of soft tissue swelling, and local tenderness of the knee or knees was recorded. The erythrocyte sedimentation rate was measured, and a blood count and sheep cell agglutination test were performed as were $x$ rays of the knees and sacro-iliac joints. A rough estimate of the volume of the effusion was made by comparing the out-patient assessment, when the volume was ascertained, with the present state, and the amount of radioactive gold which would give a dose of between 600 and 800 roentgens to the surface of that volume calculated. The procedure then was as described in the pilot study except that the therapeutic dose of $\mathrm{Au} 198$ was well mixed with the synovial fluid during the injection period. If there was any technical difficulty in obtaining a satisfactory flow of synovial fluid, a fraction of the dose only was given, the knee was then scanned and the further amount given only if this scan was satisfactory. This happened on three occasions. The o? knee was scanned approximately 6 hours after the $\Rightarrow$ injection, when satisfactory diffusion was seen in all $\stackrel{5}{+}$ cases. At 24 hours, the knee was aspirated to dryness and the volume, protein, cell count, and viscosity as well as the radioactivity of the synovial $\frac{5}{5}$ fluid were measured. From the dose of $\mathrm{Au} 198 \AA$ that had been administered initially, that in the synovial fluid at 24 hours and taking due account $\vec{\circ}$ of any which had remained in the injecting syringe and needle, a reasonably accurate assessment of the $\vec{\omega}$ total dose administered was obtained. The range $O$ of dosage varied from 480 to $1,000 \mathrm{r}$ (mean $690 \mathrm{r}$ ). Clinical assessment of the state of the knees as previously described was made on the $3 \mathrm{rd}$, 7th, and 21 st day, and subsequently at 3 months and at $t$ 1 year after the injection. If an effusion was present $\stackrel{\omega}{\sigma}$ in the knee at the 3-week and 3-month follow-up, 을 the knee was aspirated to dryness. In the fourteen cases with bilateral knee effusions, the worse knee $Z$ was treated with Au 198 initially and the other was managed in exactly the same way but inactive gold was used. The patient was discharged from hospital either after the 3rd or 7 th day.

\section{Results}

The results were classed in four grades (Table $\mathrm{I}$ )

(1) Good.-There was no clinically detectable effusion, good range of movement, and absence of $\frac{\mathcal{D}}{\mathbb{2}}$ pain and soft tissue swelling;

(2) Some Benefit.-The parameters had improved but the knee was not symptom-free;

(3) No Change.-The knee was unchanged;

(4) Worse.

TABLE I

RESULTS OF INJECTING AU 198 INTO THE KNEE JOINT

\begin{tabular}{c|c|c|c|c}
\hline $\begin{array}{c}\text { Length of } \\
\text { Follow-Up }\end{array}$ & Good & $\begin{array}{c}\text { Some } \\
\text { Benefit }\end{array}$ & $\begin{array}{c}\text { No } \\
\text { Effect }\end{array}$ & Worse \\
\hline 3 wks & 0 & 4 & 19 & 7 \\
\hline 3 mths & 8 & 15 & 7 & 0 \\
\hline 1 yr & 16 & 7 & 7 & 0 \\
\hline
\end{tabular}

The results at the 3-week follow-up were dis-o appointing as only four showed any decrease in the size of the effusion, easing of pain, or reduction of $\stackrel{\oplus}{+}$ soft tissue swelling. Seven patients were worse in $\underline{T}$ 
that they had had recurrent tense effusions during these 21 days, each requiring two or three aspirations. Fourteen showed no obvious difference from the pre-treatment state.

At the 3-month follow-up a good result was seen in eight and some improvement in five.

At 1 year sixteen showed a good result and there had been no improvement in seven. In the seven others the knee was not symptom-free, although all the reassessment parameters had improved.

In the fourteen patients with bilateral knee effusions, although the treated knees which were originally the worse did better than the control knees, there was a general tendency to improve, so that at one year four of the control knees were normal compared to ten in the treated group (Table II), and the erythrocyte sedimentation rate was normal in these four (e.g. Case 1). To date, five of the control knees have subsequently been treated, all at the patient's request.

TABLE II

STATE OF BILATERAL KNEE EFFUSIONS ONE YEAR AFTER INJECTION OF AU 198

\begin{tabular}{cc|c|c|c}
\hline Knee & $\begin{array}{c}\text { No } \\
\text { Effusion }\end{array}$ & $\begin{array}{c}\text { Smaller } \\
\text { Effusion }\end{array}$ & $\begin{array}{c}\text { No } \\
\text { Change }\end{array}$ \\
\hline Treated.. & $\cdots$ & 10 & 1 & 3 \\
\hline Control .. & $\cdots$ & 4 & 2 & 8 \\
\hline
\end{tabular}

Analysing the results at one year in the light of the underlying disease (Table III), those patients with classical rheumatoid arthritis did worst: there

TABLE III

RESULTS OF INJECTING AU 198 INTO KNEE EFFUSIONS, BY DIAGNOSIS

\begin{tabular}{|c|c|c|c|c|c|}
\hline \multirow[b]{2}{*}{ Diagnosis } & \multirow[b]{2}{*}{$\begin{array}{l}\text { No. of } \\
\text { Patients }\end{array}$} & \multirow{2}{*}{$\begin{array}{l}\text { No. of } \\
\text { Injec- } \\
\text { tions }\end{array}$} & \multicolumn{3}{|c|}{ Results at 1 year } \\
\hline & & & Good & $\begin{array}{c}\text { Some } \\
\text { Benefit }\end{array}$ & $\begin{array}{c}\text { No } \\
\text { Effect }\end{array}$ \\
\hline $\begin{array}{c}\text { Classical Rheuma- } \\
\text { toid Arthritis }\end{array}$ & 9 & 12 & 4 & 2 & 6 \\
\hline $\begin{array}{l}\text { Knees and Sacro- } \\
\text { iliac Joints } \\
\text { Affected .. }\end{array}$ & 4 & 5 & 3 & 1 & 1 \\
\hline $\begin{array}{l}\text { Ankylosing } \\
\text { Spondylitis }\end{array}$ & 1 & 2 & 1 & 1 & 0 \\
\hline Knee Effusion & 4 & 4 & 4 & 0 & 0 \\
\hline $\begin{array}{c}\text { Juvenile Rheuma- } \\
\text { toid Arthritis } \quad \text {. }\end{array}$ & 4 & 5 & 2 & 3 & 0 \\
\hline Psoriatic Arthritis & 2 & 2 & 2 & 0 & 0 \\
\hline Total .. & 24 & 30 & 16 & 7 & 7 \\
\hline
\end{tabular}

was no effect in six and some effect in two, and only four had a good result. Among those with abnormal sacro-iliac joints on $x$ ray but no back trouble, three of the five knees injected showed a good result, one some effect, and one no effect. In the patient with ankylosing spondylitis the first knee did well but the second only showed "some" improvement. Those who did best were patients with knee effusions but no evidence of other joint involvement and in one of these a synovial biopsy showed the typical histological changes of rheumatoid arthritis. In juvenile rheumatoid arthritis only two knees have done well, although the remaining three show some improvement. The two patients with psoriatic arthritis both did well: one had a Baker's cyst extending into the calf and this was completely relieved (Case 2); neither had sacro-iliac involvement.

Examination of the synovial fluid either initially or at the subsequent aspiration was of no value in ascertaining the response, but at 3 months, in those cases who derived some benefit but still had effusions, the viscosity tended to have increased.

\section{Discussion}

The technique is simple and the only real problem has been that of assessing the size of the effusion, particularly if it was large or associated with a Baker's cyst. Most of the knees which improved showed a marked reaction with heat, tenderness, and rapid re-accumulation of effusion after the first aspiration. The first few cases who showed any effusion in the days immediately following the injection had their knees aspirated and the fluid was cultured, but as no growth was obtained, aspiration was not subsequently performed until the 3rd week, unless the effusion was incapacitating the patient. Initially the results were disappointing, but by the 3-month follow-up some patients had improved, and by one year considerably more. This is in accord with the result of radiotherapy at other sites.

Three factors need to be considered in discussing these results:

(1) The tissues may not be radio-sensitive, although various workers (Desmaris, 1953; Sharp, 1954) have suggested that peripheral joints in ankylosing spondylitis are radio sensitive and one would therefore have expected certainly those cases with sacro-iliitis to respond.

(2) The radiation dose delivered to the synovial membrane may be too small, as when $x$-ray therapy has been used, doses of the order of 1,000 to 2,000 roentgens have been used (Desmaris, 1953; Sharp, 1954; Wilkinson and Bywaters, 1958). 
(3) The beta rays from $\mathrm{Au} 198$ may not have penetrated far enough to irradiate the whole thickness of the synovial membrane.

To investigate this last possibility further, one of the patients with rheumatoid arthritis who had shown no effect from a therapeutic dose of radioactive gold underwent surgical synovectomy. 24 hours before this, a tracer dose of $\mathrm{Au} 198$ was placed in the synovial fluid in the usual way and the synovial fluid and membrane were carefully studied after surgery. Little radioactivity was found in the synovial fluid, but the fibrin clot in the joint was highly active as was the synovial membrane. An autoradiograph showed the gold to be lying in the outer cells of the synovial membrane. The thickness of the cells was very much greater than $1 \mathrm{~mm}$., the average depth the beta radiation could be expected to penetrate. Thus response to therapy may well have been determined by the thickness of the lining cells of the synovial membrane, and only when these were thin did an effective radiation synovectomy occur. Further studies with serial needle biopsies to elucidate this problem are in progress.

\section{Illustrative Case Histories}

Case 1.-A man aged 42 who had bilateral knee effusions and sacro-iliitis received a therapeutic injection of radioactive gold into the right knee, and inactive gold into the left. At 3 weeks an effusion had recurred, but at 3 months, despite a further accumulation of fluid in this knee, it was less than in the untreated one. There was no accumulation after this aspiration. The control knee continued to have effusions of about the same size for 6 months, after which there was no recurrence after aspiration. The E.S.R. was high at the start of treatment and this rapidly settled (Fig. 2). The patient has been followed for 4 years and there has been no recurrence of effusion in either knee; there is no soft tissue swelling and a full range of movement. He no longer takes analgesics, the E.S.R. is normal and the D.A.T. negative, and radiological abnormality is confined to the sacro-iliac joints.

Case 2.-A man aged 47 with psoriatic arthritis had had an effusion in the left knee for 7 years with a Baker's cyst which communicated freely with the knee for the 6 months preceding therapy. This made assessment of the size of the effusion very difficult so that at 24 hours twice the expected amount was aspirated. A large effusion reaccumulated in the next 24 hours so that a second therapeutic injection was given that day. Even so the total dose was only $540 \mathrm{r}$. In the first 3 weeks he had recurrent tense effusions which were very hot and were consequently aspirated to make sure that they were not infected. After the last aspiration at 3 months he had no further effusion during a 3-yeas follow-up (Fig. 3, opposite).
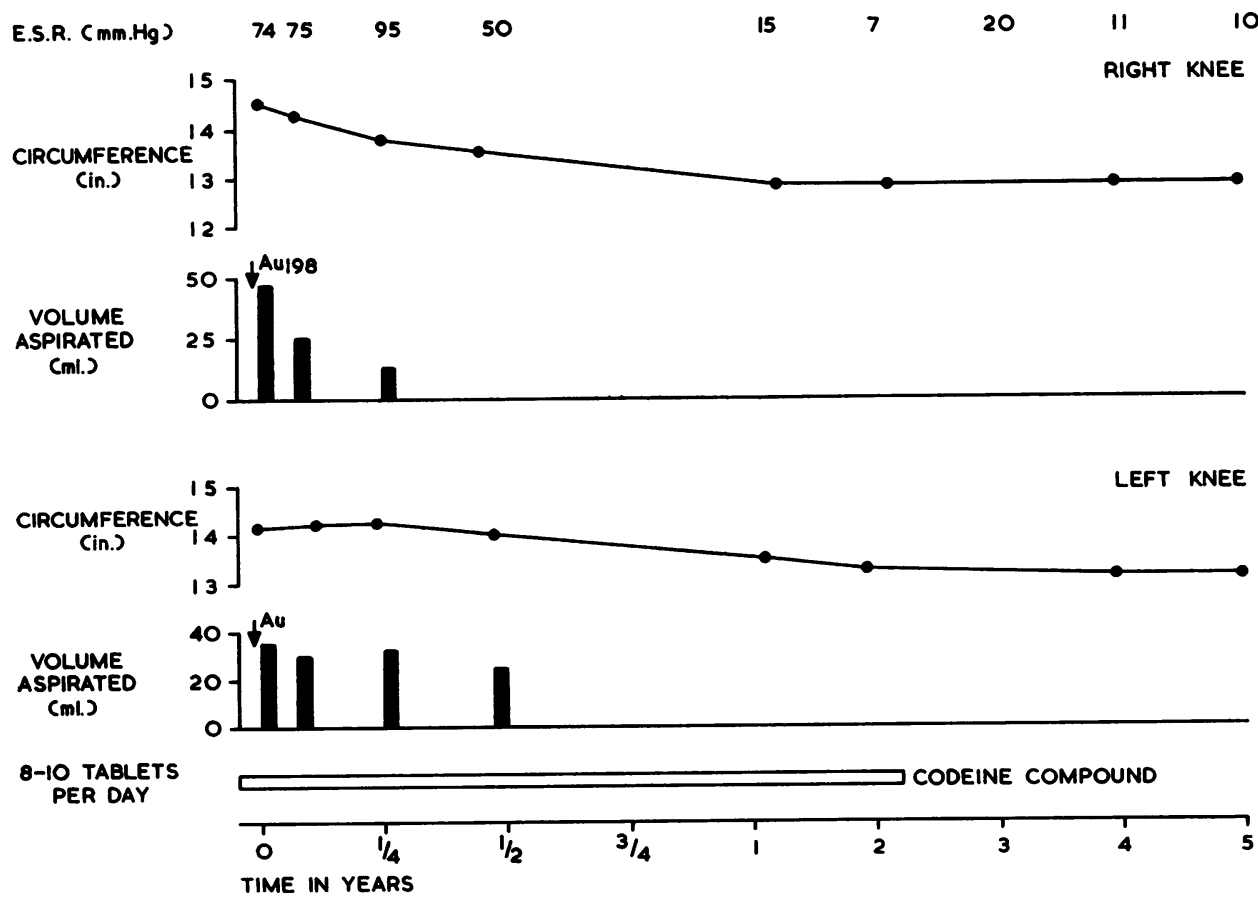

Fig. 2.-Course of Case 1 in whom response in the treated knee was followed by improvement in the control knee. 


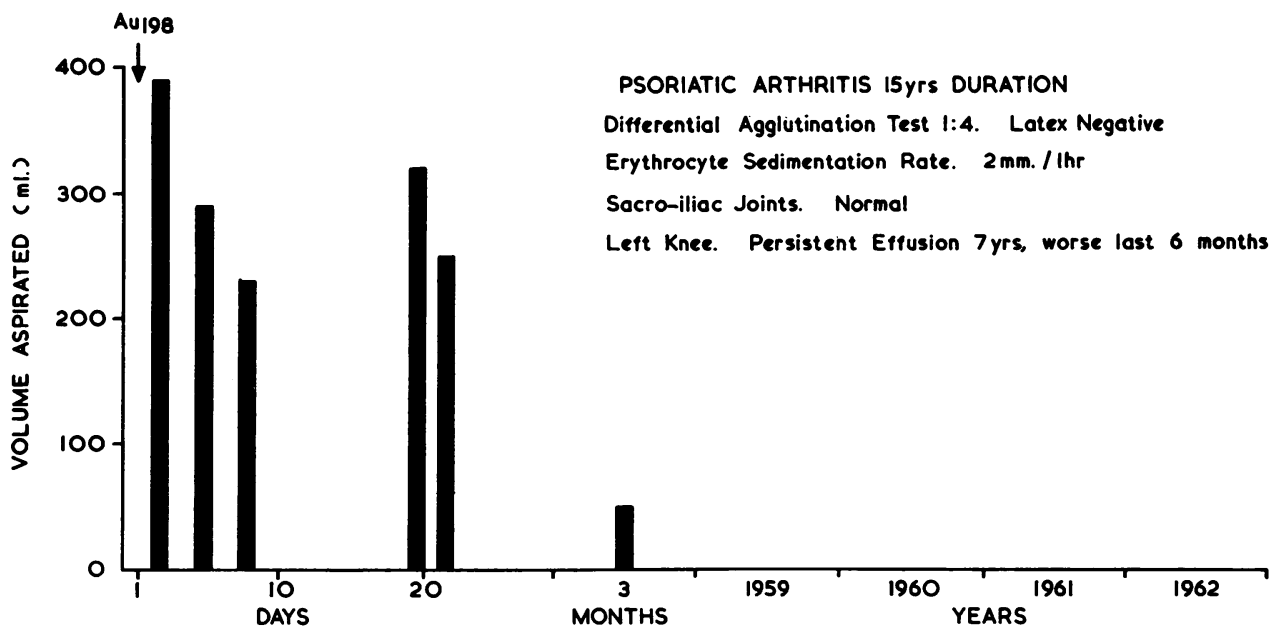

Fig. 3.-Excellent response in Case 2 with psoriatic arthritis.

Summary

(1) The introduction of radioactive gold into the knee joint allows the synovial membrane to be irradiated by particles of low penetration.

(2) The one year follow-up of thirty therapeutic injections showed a good result in sixteen, some effect in seven, and none in seven. In the fourteen cases in which bilateral knee effusions were present, the treated knee tended to do better than the control, but on four occasions the second knee had settled by one year.

(3) It is suggested that failure of this form of therapy may be due to the inability of the $198 \mathrm{Au}$ to penetrate far enough into very thickened synovial membrane. Yttrium 90, with its considerably greater penetration (over $3 \mathrm{~mm}$.) into the tissue, may be preferable and warrants further investigation.

\section{REFERENCES}

Desmarais, M. H. L. (1953). Ann. rheum. Dis., 12, 25. Sharp, J., and Easson, E. C. (1954). Brit. med. J., 1, 619 .

Wilkinson, M., and Bywaters, E. G. L. (1958). Ann. rheum. Dis., 17, 209.

Evaluation de l'or (Au 198) colloïdal intra-articulaire dans le traitement des épanchements persistants du genou

\section{RÉSUMÉ}

(1) L'introduction de l'or radioactif dans l'articulation du genou permet l'irradiation de la membrane synoviale par des particules de faible pénétration.
(2) L'observation de trente genoux injectés un an après révéla un bon résultat dans seize d'entre eux, un certain effet dans sept d'entre eux et aucun effet dans sept autres. Dans quatorze cas ou il y eut des épanchements du genoux bilatéraux, le genou traité tendit à se porter mieux que l'autre, servant de témoin, mais dans quatre cas le deuxième genou se trouva guéri au bout d'un an.

(3) On pense que l'échec de cette forme de thérapie serait dû au fait que l'Au 198 ne pénètre pas suffisamment la très épaisse membrane synoviale. L'Yttrium 90 , dont le pouvoir de pénétration (plus de $3 \mathrm{~mm}$.) dans le tissu est considérablement supérieur, est préférable et mérite des recherches ultérieures.

Valoración del oro (Au 198) coloidal intra-articular en el tratamiento de derrames persistentes de la rodilla

\section{SUMARIO}

(1) $\mathrm{La}$ introducción de oro radioactivo en la articulación facilita la irradiacion de la membrana sinovial con partículas de baja penetración.

(2) La observación un año más tarde de treinta rodillas inyectadas reveló un buen resultado en dieciseis de ellas, un cierto efecto en siete y ningún efecto en otras siete. En catorce casos con derrame en ambas rodillas, el lado tratado pareció mejor que el otro sin tratar, pero en cuatro casos la secunda rodilla se vió restablecida al cabo de un año.

(3) Se sugiere que el fracaso de esta forma terapéutica se debe al hecho de que el Au 198 no penetra suficientemente la espesa membrana sinovial. El Yttrium 90, cuyo poder de penetración (más de $3 \mathrm{~mm}$.) en el tejido es muy superior, pudiera ser preferible y merece una investigación. 